\title{
Agriculture and Kayaye (Head Porterage) Menace in Ghana: A Case of Policy or Structural Failure?
}

\author{
Abdul-Basit Tampuli Abukari (Corresponding author) \\ Department of Agricultural Economics, Faculty of Agriculture, \\ Çukurova University, Adana, Turkey. \\ E-mail: tampulia@yahoo.com
}

Seidu Al-hassan

Central Administration, University for Development Studies,

P O Box TL 1350, Tamale, Ghana.

E-mail: zodaseidu@yahoo.com

\author{
Received: February 20, $2017 \quad$ Accepted: April 17, $2017 \quad$ Published: May 18, 2017 \\ doi:10.5296/jas.v5i2.10768 URL: https://doi.org/10.5296/jas.v5i2.10768
}

\begin{abstract}
Most researches on migration have often targeted the host cities where the living conditions and the coping strategies of the migrants are documented. The push factors in their home towns and regions are theoretically being referred. The most common among the factors are poverty and unemployment resulting from the dwindling fortunes in agriculture. The study selected the Northern region because it is the largest, both in terms of agriculture and the supplier of migrants for the kayaye business. The outmigration of this group of people has remained a serious socio-economic dilemma for policy makers in Ghana. The study sets out to review why some selected key policies have failed to reverse this menace. At the same time it examines the structural economy of the region which is generally agricultural. Three different quantitative techniques are used to determine the relationship between labor and agricultural production. Results of all these techniques suggest a significant reduction in the labor employed in agricultural production. This brought to light how agriculture, the traditional occupation of these migrants rejects their labor. With educational and skills barriers to the industry and services sectors, the kayaye business is an inevitable alternative. In the light of these findings, policy recommendations have been provided.
\end{abstract}

Keywords: Kayaye (Head Porterage), Unemployment, Agriculture, Migrants, Policy 


\section{Introduction}

Migration (human) is the movement of people from one place to another for the purpose of taking up permanent or temporal residence. The movement can either be within the country (Internal Migration) or across the border (International Migration), it can be voluntary or involuntary, it can also be seasonal or non-seasonal (Asare, 2012). In the Ghanaian context, the word 'kaayaye ${ }^{1}$, denotes a female migrant from the north to the southern cities (mostly Greater Accra and Ashanti regions) to earn their living through head porterage. The migrants are largely uneducated, unskilled or school drop-outs from rural agricultural communities from the three Northern regions (Upper East, Upper West and Northern). Kumasi, Accra and Sekondi-Takoradi are the most patronized cities for these migrants (Agyei et al., 2016). For consistency, we will stick to 'kayaye' (kayayee, plural). There have been a wide range of technical definitions for this term. We adopt that of Opare (2003); 'Kayayoo is thus a young woman or a teenage girl who carries other people's loads on the head for a fee'. It has to be noted that in the singular form of the word, it denotes both the activity and the person carrying it out (Mahama, 2015). When the term is used in the sense of the activity, it denotes all forms of petty jobs including head porterage. In other words, when they say a person has gone to kayaye, it simply means that he or she has gone to the city in search of petty jobs. In this context, it can be concluded that, even though females form the majority of migrants for the kayaye business, some male counterparts do also migrate. The records on the population of the Kayayee are lacking as there has been few surveys done on them (Agyei et al., 2016). However their growing presence in the bigger cities gives an indication of their influx. According to Kearney (2013), there are an estimated 160,000 Kayayee in the capital city (Accra) alone, with an annual 15,000 addition from the Northern regions. The evidence of increasing patronage of this business is not only in the increasing numbers in the old cities but their spread to new cities, like Koforidua (Agyei et al., 2016).

Even though migration has historically been a peripatetic tradition of some ethnic groups, the real reason why people migrate is the roving human instinct that drives them to search for food, pasture, resources, as well as explore and conquer (King, 2012). At any point in time, there are 'negative' factors pushing migrants away from the current location and 'positive' factors in the destination pulling them or a combination of both. These have come to be known in migration literature as push and pull factors. The push factors can be economic (poverty, lack of employment, low productivity and efficiency in agriculture etc.), social (inadequate health and educational facilities, forced marriages, etc.), environmental (drought and famine, degrading agricultural lands, crop failure, climate change etc.), demographic (high birth rate, overcrowding, marriage etc.) and political. The pull factors are mostly hopes for improved conditions in the host cities (Kainth, 2010; Lucas, 2015; Lucas, 1997; Thet, 2014).

Policy oriented discussions on migration are often divided on the relative importance of the pull and push factors. Some researchers have argued that push factors constitute real problems in the rural areas that already need more attention. The pull factors are already

\footnotetext{
${ }^{1}$ Also known as kayayoo
} 
positive things in the urban areas, which in any case need to be maintained if it cannot be improved. Another group stressed the need not to downplay the roles of each as they simultaneously affect the decision of migrants (Kainth, 2010). This has dictated the focus of researches in this field. While some researches are done in the host cities, others are conducted in the places of origin. The former has received a lot of attention. For the first time per our knowledge, this study intends to subject unemployment as the most important push factor, to an empirical quantitative analysis, in Ghana. The scanty amount of literature in this aspect is not only a big gap but a significant one.

The source of employment for these migrants is agriculture. About $73 \%$ of the inhabitants in the region are into agriculture (GSS, 2012). With little education and skills, these potential migrants are automatically rejected by the industry and service sectors. Their only resort is farming, which requires little or no education and special skills to practice. However, at early ages they are used mostly as family labor. The region produces the highest number of migrants for the kayaye business, as it is predominantly Muslim Mole Dagbani (UNFPA, 2013). With continuous patronage of the kayaye business, the question arises; is it is the case of policy failure or agriculture is also rejecting these labors? If yes, how are they being rejected? It is obvious that their rejection from the industries and service sectors are not the same as in agriculture; whiles the industry and service sectors have education, skills and experience barriers to entry, agriculture is almost a free-entry free-exist sector.

\section{Literature Review}

\subsection{Theoretical Framework}

The study reviews implemented government policies that in our opinion are directly or indirectly linked to the reversal of this trend. Furthermore, the status of agricultural employment in the form of labor is analyzed using primary agricultural production data in the region. The framework is summarized in Figure 1.

The policies that are directed towards improving the living conditions of the migrants in their destinations are in our opinion unsustainable. However, this has received a lot of attention and scholarship more than those that reduce their migration. There is no restriction to entry and exit from the kayaye business, hence any attempt in improving their living conditions will attract more migrants. Unless there is a concurrent policy that seeks to discourage their migration, those policies cannot be sustainable. 


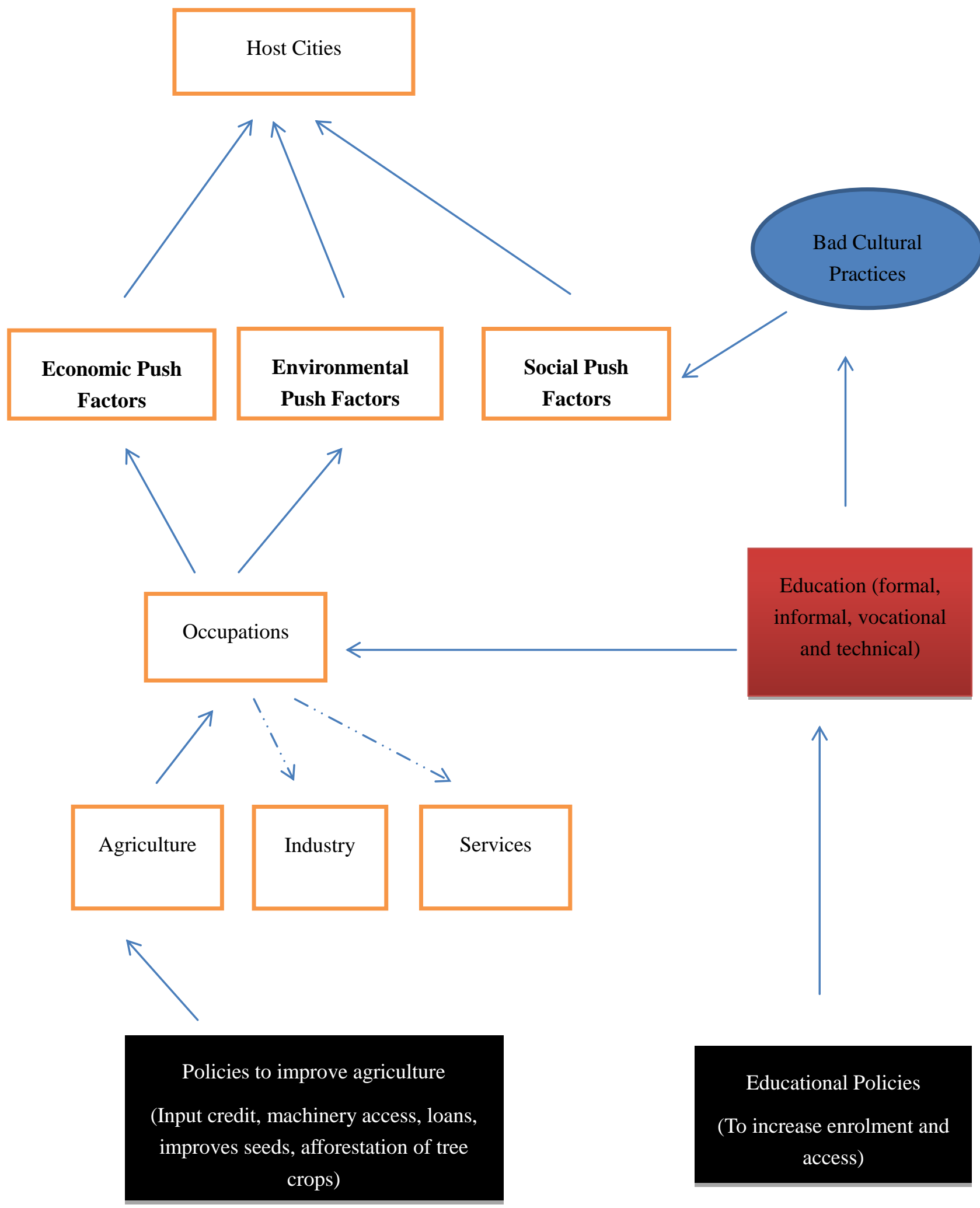

Figure 1. Policy framework to reducing kayaye business 
We have posited that for any policy to have a significant effect in reducing the migration of Kayayee, they must be agriculturally or educationally oriented. The justification for agriculture stems from the fact that, it is the original occupation of most of the migrants. In the off-farming season, most especially females resort to gathering and processing of shea and dawadawa. These are the main tree crops in the region. Therefore improving agriculture means the livelihoods of most of the potential migrants are being improved. Education which can be in the form of formal, informal, technical and vocational studies will have both immediate and long term effect in reversing this trend. Formal education will instantly retain the under aged and the school going potential migrants in school. The other forms of education prepare them for job opportunities in the informal sector, which requires a certain level of education and training. The combined effect of education can reduce the effect of gender bias cultural practices, which push females to kayaye. These together will reduce the migration to the host cities.

\subsection{Kayaye Phenomenon}

Labor migration has existed for a long time between the north and south of the country. The north has historically been considered a labor reserve for the highly resourced rich south. Not only was it considered as such, but policies were deliberately made to promote it (Awumbila, 2007). As far back as 1919, a development plan by the then colonial Governor Gugisberg, suggested the need for 27000 men as labor in the mines and cocoa farms in the south. These men were to be recruited from the Northern regions (Tanle, 2014). Even though this practice ceased shortly before independence in 1957, labor migration never ceased as a direct response to the deliberate and inherited pro-south development policies. Migration became voluntary rather than the forced recruitment process. This explains why the Northern regions have consistently experience a net loss of people to the Southern regions (Anarfi, and Kwankye, 2005). The forest and the coastal belt received a lot of attention by way of developing mines, improving cash crops, lumbering and the creation of ports and harbors. All these came with massive infrastructural development in the form of roads, railways, schools etc. (Wrigley-Asante, 2013; Van den Berg, 2007). From the time of the forced recruitment to the voluntary migration after independence, these men from the north were not engaged in porterage. It was the preserve of foreign males, mostly from Sahelian countries of West Africa. In the wake of the Aliens Compliance Order in 1969, these foreigners were expelled, which left a vacuum in the porterage industry. This vacuum was filled by the men from the north, who used wheeled carts. Rapid urbanization soon required that load carried on the head is more efficient and cost effective than the carts that add to the vehicular traffic. Since head porterage has traditionally been the work of women, it was not long that the females from the Northern regions joined the business and has since dominated it (Kwankye et al., 2007; Awumbila et al., 2008; UNFPA, 2013). The foreigners who were mostly Hausa called the business 'kaya', which means load. When the Ghanaian women took over the business, the local people in the capital added 'yoo', which means woman. Hence 'Kayayoo' or 'Kayaye', translates to 'a woman who carries loads' 


\subsection{Feminization of Kayayee}

In the context of the Northern region, the push factors for kayaye are generally gender biased, contributing to its feminization. Literates are less likely to embark on kayaye. However, in the adult population of the Northern region, more than half of the female population have never attended school, making it the highest in the country (GSS, 2013). Among children of school going age, the statistics is yet not in favor of females. Not only the school attendance rate in the Northern region is the lowest $(50.4 \%)$, it experiences the widest gap between the sexes (GSS, 2014). It can therefore be concluded that there are more illiterate female adults and more non-school going female children than males in the Northern region. In terms of unemployment, females are generally less employed than males in Ghana. However, in the rural areas a chunk of those employed females are contributing to family labor; male $(21.5 \%)$ and female (38.5\%) (GSS, 2014). One other key factor feminizing kayaye is the socio-cultural issue of early and forced marriages. When females are pressured to marry early, it means they should find a faster way to acquire possessions necessary for the marriage life. Since such opportunity is not available, kayaye is the surest option. In the case of forced marriages, females often use kayaye as an escape route. Still in the context of marriage, divorced or widowed women, who often find it difficult coping with life turn to kayaye (Adepoju, 1986). In a largely polygamous society like the Northern region, married women embark on kayaye, in order to acquire possessions to outshine the rival and attract the husband's attention (Opare, 2003). In view of all these, Mahama's (2015) description of kayaye as a 'desperate job' for rural females could not have been far from correct.

\section{Materials and Methods}

\subsection{Data and Sample Selection}

Data was gathered on all important crops grown in the region for the 2014/2015 farming season. The outputs of various crops were monetized based on the average retail prices of output as at September 2014. September is the expected harvest for most crops. The monetization was necessary to avoid aggregation challenges. Farm gate prices were not readily available because they did not have records of time, quantity and price of sales of their output. The sales are normally done in piecemeal and in most cases not by the farmer. Therefore, the regional retail prices of all the crops in question were taken from the Statistics, Research and Information Directorate (SRID) of Ministry of Food and Agriculture (MoFA), as an approximation for the per unit output prices. These crops are maize, rice, millet, soybean, sorghum, groundnuts, cowpea, cassava, yams.

The inputs considered are land size, labor, machinery, fertilizer and pesticide. Land area represents the total number of acres on which these crops are planted. Labor is the total number of labor hours spent on each crop for all the production activities. This involves family and hired labor. Machinery measures the total number of hours machines are used in the production processes for all the crops. Fertilizer represents the total weight $(\mathrm{kg})$ of fertilizer acquired and applied in the production of these crops. Pesticide use refers to all types of chemicals used in the control of weeds, pest, fungi and ruminants. These chemicals come in various forms like liquid, grains, powder etc., as such physical quantity aggregation 
is almost impossible. Like output, the study converted it to the total amount in Ghana cedi (GHC) spent on these chemicals. Data on per-unit prices of all the above inputs, except pesticides were also collected or estimated. This is because there is no one particular physical unit for the measurement of pesticide; while some are measured in liters, others are in weights, grains, etc. The per-unit price of land is the price of $100 \mathrm{~kg}$ bag of maize which is usually given per acre if the land does not belong to the farmer. This is given after harvest, hence the per-unit price is the price of $100 \mathrm{~kg}$ of maize as at September 2014, the expected time of most harvests. That of labor is the average price he or she bargained for hired labor per hour. Machinery is the total cost of machinery divided by the number of machinery hours. For fertilizer, it is the total fertilizer cost divided by $50 \mathrm{~kg}$ (the weight of fertilizer bag).

The sample selection for this study was multi-staged. A random sampling technique was used to determine the number of districts from which the sample would be selected. Secondly using proportional allocation, a targeted sample of 100 is divided equally among the selected districts. However, to cater for none-response and incomplete information, a target of 120 was reached. Subsequently 109 respondents were used. The selection of the final farmers to be interviewed was purposive in the sense that only farmers who had returnee migrants or Kayayee in their agricultural labor were considered. There were instances where the respondent is a returnee migrant.

\subsection{Methodology}

The study adopts a mixed methods research design. For this type of study, employing only qualitative or quantitative methods would not provide all the answers needed for doing justice to the topic under discussion. The first part of the analysis involves the description of attempted policies or programs that have direct and indirect impact on the migration of youth from the north to the south. There has not been a national policy specifically aimed at reducing participation in the kayaye business. However, some policies have integrated it into their broader policy frame work. The purely quantitative techniques used are further divided into two; stochastic and non-stochastic techniques. The stochastic techniques include the estimation of the output elasticities of inputs and the estimation of the Resource Allocation Coefficient (RAC). The slacks analysis is the only non-stochastic technique. All these techniques are directed towards the status of agricultural labor in agricultural production in the region.

\subsubsection{Output Elasticities of Inputs.}

Output elasticity of any input is the proportionate change in output caused by a proportionate change in that input, keeping all other inputs constant (Wolken, 1970). The summation of all the output elasticities gives the Returns to Scale (RTS) of the production process. The process involved in this estimation is econometric, and will involve the invocation of certain assumptions. First is the RTS and secondly, the production function.

The RTS assumption is necessary in the estimation of any production function. It may be Constant Returns to Scale (CRS) or Variable Returns to Scale (VRS). The production process is experiencing a CRS if the proportional change in all input results in the same proportional 
change in the output. Under VRS, it can be Increasing Returns to Scale (IRS), CRS, or Decreasing Returns to Scale (DRS). When the proportionate change in all inputs results in a more than or less than proportionate change in output, then the production process is experiencing IRS or DRS respectively (Rasmussen, 2011). Without any theoretical explanation to the choice of RTS, we settle for both CRS and VRS assumptions. However, a hypothesis test would still be conducted

The second issue is the production function. There are two decisions to be made under this; 1 . Whether the production will be deterministic or stochastic? 2. Which functional form would be used in the estimation of the production function? A generalized production function is expressed as in Equation 1, irrespective of the functional form and the RTS assumption.

$$
Y_{i}=f\left(X_{i} ; \beta_{i}\right)+\varepsilon_{i}
$$

Where

$$
\varepsilon_{i}=v_{i}-u_{i}
$$

The function is made up of the deterministic component $\left(f\left(X_{i} ; \beta_{i}\right)\right)$ and the error component $\left(\varepsilon_{i}\right), Y_{i}$ represents the output of the various crops considered in the study, $X_{i}$ is the vector of the inputs employed, $\beta_{i}$ is the output elasticities of inputs employed, and $\varepsilon_{i}$ is the composed error. This is defined in Equation 2 as the summation of the statistical noise $\left(v_{i}\right)$ and the inefficiency term $\left(u_{i}\right)$.

The function is deterministic if it takes the form of Equation 1, and it is stochastic if Equation 2 is substituted into 1 . While stochastic production functions takes into accounts stochastic elements, determinist functions do not. Since stochastic elements like bad weather, pests, diseases, government policies, natural disasters etc., significantly affect agricultural production, we opt to use the stochastic production function (Silva et al., 2013). The estimation of the functions would be done using NLOGIT 5.0. For the second decision, the choice is mostly between the Cobb-Douglas and the Transcendental Logarithmic Production (translog) Functions. Using the likelihood ratio test, the data will determine which of the production functions fit it better.

Unlike the deterministic production function, where the error term is symmetrical and assumes a normal distribution, the term $u_{i}$ in the stochastic production function is not symmetrical hence cannot be normally distributed. This brings us to another hurdle, distributional assumption of $u_{i}$. There are basically four different types of distributional assumption for the $u_{i}$ term; Half-normal, truncated-normal, exponential and gamma distributions (Kumbhakar and Lovell, 2000). All the four distributions would be considered and the functions compared.

Statistical tests would be conducted to either further discussions or make a decision. From the discussions above, a test would be conducted on the RTS assumption, between the choice of Cobb-Douglas and Translog production function, and whether there is production inefficiency in the production process. These tests would be conducted using the generalized likelihood ratio statistic, given as; 


$$
L R(\lambda)=-2\left\{\ln \left(\frac{L W}{L U}\right)\right\}=-2\{\ln (L W-L U)\}=-2\{\ln [L(H 0)-L(H 1)]\}
$$

Where $\ln (\mathrm{LW})$ is the value of the log likelihood function for the restricted frontier model and ln (LU) being the value of $\log$ likelihood functions for the unrestricted model. The distribution follows a chi square distribution hence the use of the chi square statistic to make the decision. Even though it takes a great deal to go through all these processes, the statistic of interest in the final production function irrespective of the RTS or distributional assumption is the $\beta_{i}{ }^{\prime}$ s in Equation 1; that is, the output elasticities. This unitless statistic maybe positive or negative; a positive indicates an addition to output by a proportion that commensurates the value of the elasticity coefficient. A negative indicates otherwise. In terms of physical addition to output, all things being equal, farmers would not attempt increasing inputs that would lead to a decrease in output. However, for inputs with positive output elasticities, the degree of increment varies with the output elasticity coefficient. When an input is increased, output may increase insignificantly or a considerable amount depending on the value of the coefficient.

\subsubsection{Resource Allocation Coefficient (RAC)}

Under profit maximization assumption, not all the inputs with positive output elasticities are worth increasing. This coefficient dictates which inputs should be reduced and those that should be increased irrespective of their output elasticities; that is, input allocation. This is done by comparing the value (income) of the increase in output that would result from a unit increase in input to the unit price of that input. It measures how inputs are efficiently allocated to production. The formula is given as the ratio of the input's value of marginal product $\left(\mathrm{VMP}_{\mathrm{i}}\right)$ to the unit price of the input $\left(\mathrm{P}_{\mathrm{i}}\right)$ under consideration (Dilmen, 1976; Grazhdaninova and Lerman, 2005). For a Cobb-Douglas production function, the marginal product $\left(\mathrm{MP}_{\mathrm{i}}\right)$ is,

$$
M P_{i}=\frac{d y}{d x}=\beta_{\mathrm{i}} * \frac{\overline{\mathrm{Y}}}{\bar{X}_{i}}
$$

$\beta_{\mathrm{i}}$ is the estimated output elasticity of the input, $\bar{X}$ and $\bar{Y}$ are the geometric means of the inputs and output respectively. The geometric means are used because these variables are in their natural logarithms in the production function.

The formula of RAC is given as;

$$
R A C_{i}=\left(P_{y} * M P_{i}\right) / P_{i}
$$

Where $\mathrm{VMP}_{\mathrm{i}}=\mathrm{P}_{\mathrm{y}} * \mathrm{MP}_{\mathrm{i}}, \mathrm{Py}$ is the per unit price of output.

In the specific case of this study, there is no need to multiply the price of output $\left(\mathrm{P}_{\mathrm{y}}\right)$ by the marginal product $\left(\mathrm{MP}_{\mathrm{i}}\right)$ to get $\mathrm{VMP}_{\mathrm{i}}$, since output is already in monetary units comprising of all the output prices. Therefore $\frac{d y}{d x}=V M P_{i}$

If the RAC ratio is less than one, it means an increase in the input will result in an income 


\section{Macrothink}

Journal of Agricultural Studies

ISSN 2166-0379

2017, Vol. 5, No. 2

that is less than the cost of increasing that input, hence that input is over utilized and should be reduced. If it is one, that input is efficiently allocated and should not be changed. Finally, if it is greater than one, it means the value (income) of output resulting from the unit increase is more than the cost in increasing that input. This implies that the input is underutilized and should be increased for more income benefits to the farmer. To this end, the analysis suggests that inputs with RAC below one should be substituted for those above one; that is, input or resource allocation. Put differently, the increase in inputs with RAC below one makes the farmers poorer, and those above one makes them richer. One point to note is that, the RAC for pesticide as an input cannot be estimated since its per-unit price could not be estimated.

\subsubsection{Analysis of Slacks}

From the deterministic (non-stochastic) analysis of the production frontiers, production entities can still not be employing the minimum quantity of inputs despite producing on the frontier. This phenomenon occurs when there are slacks in the input use (Cooper et al., 2007). By definition, input slacks are seen as wastage. The presence of input slacks makes the farmer inefficient. Some authors according to Coelli et al. (2005) use the term input excess instead for easy understanding. In a nutshell, this analysis is going to reveal which among the inputs is excessively used from the technical production point of view.

Like the production function, the estimation of the input slacks is considering both VRS and CRS assumptions. It is also input conserving since the target is on input slacks. The estimation is done by series of linear programming which minimizes efficiency subject to some constraints (Ramanathan, 2003). The linear programing is as follows:

$\min \theta_{\mathrm{m}}$

Subject to;

$\sum_{n=1}^{N} y_{j n} \lambda_{n} \geq y_{j m} ; j=1,2,3, \ldots \ldots \ldots . J$

$\sum_{n=1}^{N} x_{i n} \lambda_{n} \leq \theta_{m} x_{i m} ; \quad i=1,2,3, \ldots . I$

$\sum_{n=1}^{N} \lambda_{n}=1$

$\lambda_{\mathrm{n}} \geq 0 ; \quad \mathrm{n}=1,2,3 \ldots \ldots \ldots \mathrm{N}$

$\theta_{\mathrm{m}}$ unrestricted (free)

$\theta$ is the efficiency estimate, $\lambda$ is the weight of farmer involved, $x$ and $y$ are inputs and output 
respectively, $\mathrm{n}$ represents farmers, while $\mathrm{m}$ is the farmer under consideration. Equation 8 is the VRS restriction, which makes sure that firms are compared with firms of the same scale, without which the model is CRS (Coelli, 2005). This model would be estimated using the Data Envelopment Analysis Program (DEAP Version 2.1). When this model is optimized, technical efficiencies, target inputs and input slacks of each farmer are estimated in the output file of the software.

\section{Results and Discussions}

\subsection{Attempted Policies}

By far, the most effective agricultural policy in the history of Ghana is the 'Operation Feed Yourself' (OFY). It was dubbed Ghana's Green Revolution by some authors. It was launched by the military government under General Ignatius Kutu Acheampong from 1972 to 1978. It was aimed at achieving self-sufficiency in agricultural production, in response to the drought that swept across the Sahelian region (Girdner et al., 1980). It saw the importation of agricultural machinery and the construction of dams. Agricultural inputs were also heavily subsidized. Ghana was not only self-sufficient in food production but a net exporter in the first three years of the program (Woode, 2012). Even though it was a national program, the Northern regions stood to benefit more because most of them were farmers. Though the policy had its implementation challenges, Jawula (2010) suggested that the wide implementation of this policy across the various agricultural fields in the Northern region contributed to the reduction in migration. The assertion of Jawula (2010) seems to be supported by data from the studies of Anarfi, and Kwankye (2005). Using data from Census reports of 1960, 1970, 1984 and 2000, they established that prior to 1960 and between 1960 and 1970, the region experienced a loss in net migration. However, a net gain was experienced between 1970 and 1984, which was the implementation period of the policy. Thereafter, there has never been a net gain, with the net loss continuously rising annually.

The Tree policy, which was developed under the framework of the Medium Term Agriculture Sector Investment Plan (METASIP) 2011 - 2015 targeted citrus, cocoa, coconut, coffee, kola, mango, oil-palm, rubber, cashew, dawadawa and shea nut. The last three were classified as those grown in the ecological zone of the Northern region. Coincidentally, with the exception of cashew, the rest were classified further as wild. However, as mentioned earlier these same tree crops keep the youth especially girls employed in the dry season, thereby preventing them from migrating. According to the policy document, dawadawa and shea are the main cover crops in the Northern region with immense economic importance. Apart from the local consumption, shea for instance is an important export crop for the pharmaceutical and cosmetic industries. It further mentioned the processing and marketing prospects of these crops but admitted that afforestation will always be a challenge compared with other tree crops. Lack of improved planting materials and the long gestational period were the reasons cited, and that researches are being conducted into reducing the gestational period of these crops (MoFA, 2012). According to Al-hassan (2012), University for Development Studies (UDS) and Savanah Agricultural Research Institute (SARI) are leading in the research to have them grown like the other tree crops in the Southern regions. Going by the policy 
document, these migration curbing tree crops would receive all other benefits like other crops in the Southern region except afforestation. However, these trees are destroyed at a faster rate than any other tree in the region (Al-hassan, 2016). Since the launch of this policy in 2012, there has not been any official report on its progress. This may be due to lack of funding as an estimated amount of 157 million US dollars (US\$) was required for its implementation. We have also gone through annual progress reports of MoFA since the launch of this policy. There were no traces of the implementation of this policy. However, from 2013 the Northern Rural Growth Programme (NRGP), distributed Shea seedlings to farmers for onward plantation along water bodies used for irrigation. This was purely for environmental reasons to protect and enrich those zones. 2000 and 2250 seedlings were distributed in 2013 and 2014 respectively (MoFA, 2013 and 2014). The Tree policy itself per the document would not increase the population of these crops like it planned for other trees like cocoa, oil palm etc.

Another significant policy that has a direct bearing on the agricultural employment situation in the Northern region is the Livestock Development Policy. Most of the livestock production in the country comes from the Northern regions (Choudhary et al., 2015). The region therefore stands the chance in benefitting in terms of employment if this sector is improved. Livestock has also proven to be an important wealth and income creating asset in the rural communities. The policy was implemented in 2004 under the Livestock Development Policies and Strategies (2004-2015) (MoFA, 2004). The policy was a failure as admitted in the revised version. The failure of the previous one gave birth to the new one that spans from 2016 to 2025. According to the new policy document, challenges that lead to the implementation problems in the previous one have been addressed (MoFA, 2016).

The agricultural related President's Special Initiative (PSI) under President Kufuor was another policy implemented to improve the production of very important food crops nationwide. It was designed in such a way that every region will receive a boost in the production of the crops they produced most. It started with cassava and oil palm (Asante, 2012). The Northern region could not benefit from this program because it was discontinued in 2007. Furthermore the sorghum, groundnuts and cotton initiatives could not take off before the collapse of the program. These were the crops earmarked for the Northern region. This could have had similar effects on migration like the OFY.

There have also been recent policies by governments to increase employment of the youth. The Ghana Youth Employment and Entrepreneurial Development Agency (GYEEDA), which replaced the National Youth Employment Program (NYEP) has offered temporal and permanent employment to the youth. A module under this program dubbed Youth in Agriculture Program (YIAP) has been in operation for some time now. It aims at increasing the interest of the youth in agriculture. However, the program has been facing funding challenges which impedes its implementation (Egyir, 2013). A more specific government initiative which has now passed as an authority is the Savannah Accelerated Development Authority (SADA). This is mandated to improve the economic condition of the regions within the Northern Savannah Ecological Zone (NSEZ), through a comprehensive and long-term development planning. The takeoff was shaky from 2010, as several corruption allegations and misappropriation of funds were discovered forcing the government to 
restructure it under new management. Even though their mandate is wide, it is expected their programs will go a long way to assuage the unemployment and poverty situation in the region. This will in turn reduce the number of youth migrating to kayaye.

Education related polices have succeeded over the years in increasing school enrolment. Since most of the migrants are illiterates or school dropouts, increase in enrolment and retention could reduce their migration as explained earlier. The Free Compulsory Basic Education (FCUBE), the School Feeding Program (SFP) and the Non Formal Education (NFED) have all succeeded in increasing school enrolment and quality. Because they are national programs the educational gap between the Northern and the Southern regions continues to exist, in terms of enrolment rate, retention rate, completion, teacher student ratio, examination results and gender equality in education. For these disparities, the program implementation should be skewed towards the Northern regions in order to close the gap.

Some of these policies have succeeded in reversing the trend for a short term, others have failed, the effects of some cannot be determined, and some are too early to be assessed. It is therefore not surprising some of these policies have appeared in the policy recommendations of authors on this topic. In all those recommendations, suggestions were made to restructure the policies to incorporate the objective of reducing migration to the kayaye business. Egyir (2013) for instance suggested a restructuring of the Youth in Agriculture Program (YIAP) to make it more attractive to the youth. She suggested the modification of the existing modules and the introduction of a 'new face'; the private sector. Adaawen and Owusu (2013) argued that the already existing Ghana National Youth Policy which begets all other youth oriented policies should be looked at. Although the policy itself underscores the role of youth empowerment in the development of a nation, the rolled out programs have not been successful in addressing the kayaye issue. Anarfi and Kwankye (2005) made a suggestion on the now defunct Presidential Special Initiatives (PSIs) to be revitalized and redirected to the provision of off-season employment and alternative employment opportunities for youth in the Northern region.

\subsection{Production Functions and Output Elasticities}

Data on production used in the estimation of the production function is summarized in the Table 1 below. The mean, minimum, maximum and the standard deviation (STD DEV) estimates of the variables are only variable specific and cannot be compared. However that of Coefficient of Variation (COV) can shed more light on the STD DEV among the variables. It measures which variable is more dispersed as opposed to the other. It can be observed that labor has the highest variation. This is not surprising as most of the labor used is family labor, which depends on family size. Next in terms of variability is pesticide use, followed by land size and machinery use and then fertilizer application. The unit prices with the exception of output and pesticide use are given in the lowest row of Table 1.

The results of the hypotheses tests are summarized in Table 2. All the results of the distribution showed the same decision in the hypotheses tests. For the sake of space we present only the results of half-normal results for both CRS and VRS. 
Table 1. Summary of production data

\begin{tabular}{|c|c|c|c|c|c|c|}
\hline & $\begin{array}{l}\text { Maize } \\
\text { Output } \\
\text { (GHC) }\end{array}$ & $\begin{array}{l}\text { Land Size } \\
\text { (acres) }\end{array}$ & $\begin{array}{l}\text { Labor } \\
\text { Hours }\end{array}$ & $\begin{array}{l}\text { Machinery } \\
\text { Hours }\end{array}$ & $\begin{array}{l}\text { Fertilizer } \\
(\mathrm{Kg})\end{array}$ & $\begin{array}{l}\text { Pesticide } \\
\text { Use } \\
(\mathrm{GHC})\end{array}$ \\
\hline Mean & 8725.5 & 16.9 & 3627.4 & 55.7 & 931.7 & 164.5 \\
\hline Minimum & 1205.3 & 3.0 & 332.3 & 3.0 & 150.0 & 21.6 \\
\hline Maximum & 39021.0 & 60.0 & 23242.5 & 226.0 & 3800.0 & 862.5 \\
\hline STD DEV & 7044.7 & 10.9 & 3822.5 & 41.6 & 697.6 & 147.5 \\
\hline $\mathrm{COV}$ & 80.7 & 64.7 & 105.4 & 74.7 & 74.9 & 89.7 \\
\hline $\begin{array}{l}\text { Unit prices } \\
(\mathrm{GHC})\end{array}$ & - & 120 & 2.8 & 14.3 & 1.9 & - \\
\hline
\end{tabular}

Table 2. Results of hypotheses tests

\begin{tabular}{|c|c|c|c|c|c|}
\hline $\begin{array}{l}\text { Null } \\
\text { Hypothesis }\end{array}$ & $\begin{array}{l}\text { Log-Likelihood } \\
\text { Function (H0) }\end{array}$ & $\begin{array}{l}\text { Log-Likelihood } \\
\text { Function (H1) }\end{array}$ & $\begin{array}{l}\text { Test } \\
\text { Statistic } \lambda\end{array}$ & $\begin{array}{l}\text { Critical Value } \\
\left(\mathrm{X}_{\mathrm{I}}^{2} 0.05\right)\end{array}$ & Decision \\
\hline $\begin{array}{l}\mathrm{H}_{0}: \beta_{1}+\beta_{2} \\
+\ldots+\beta_{5}=1\end{array}$ & -7.59 & -7.53 & 0.125 & $\chi_{1}^{2} 0.05=3.841$ & Accept \\
\hline $\mathrm{H}_{0}: \beta_{\mathrm{kj}}=0$ & $\begin{array}{l}-7.59(\mathrm{CRS}) \\
-7.53(\mathrm{VRS})\end{array}$ & $\begin{array}{l}-1.11(\mathrm{CRS}) \\
-0.47(\mathrm{VRS})\end{array}$ & $\begin{array}{l}12.96(\mathrm{CRS}) \\
14.12(\mathrm{VRS})\end{array}$ & $\chi_{15}^{2} 0.05=24.99$ & Accept \\
\hline $\mathrm{H}_{0}: \gamma=0$ & $\begin{array}{l}-10.8(\mathrm{CRS}) \\
-10.1(\mathrm{VRS})\end{array}$ & $\begin{array}{l}-7.59(\mathrm{CRS}) \\
-7.53(\mathrm{VRS})\end{array}$ & $\begin{array}{l}6.43(\mathrm{CRS}) \\
5.29(\mathrm{VRS})\end{array}$ & $\chi_{1}^{2} 0.05=3.841$ & Reject \\
\hline
\end{tabular}

The first hypothesis accepts that the sum of all the output elasticities is one. This indicates that the production function is exhibiting a CRS. The second hypothesis, which seeks to claim that the interactive variables that differentiate translog from Cobb-Douglas production functions are zeros, is accepted. This means that the Cobb-Douglas production function is appropriate. Accordingly, all the production under all the RTS assumptions, assumed Cobb-Douglas production function. The last hypothesis rejects the statement that there is no 
inefficiency in the use of inputs for agriculture in the region.

Table 3 shows the estimated production functions for all the distributional assumptions across both RTS assumptions. The statistical significance of all the coefficients (Coef.) which represents the output elasticities of the various inputs is consistent for all the distributional assumptions across all the RTS assumptions. Machinery and fertilizer use are the only inputs with statistically significant output elasticities. The results for all the distributions show a very slight Decreasing Returns to Scale (DRS). However, the result of the hypothesis test indicates that those DRS are actually not significantly different from CRS. This adds credence to the School of Thought that believes agricultural production exhibits CRS. Across all distributions, fertilizer application recorded the highest value of output elasticity. This indicates that for a $1 \%$ increase in fertilizer use, it would add the highest to output compared to the other inputs.

Table 3. Estimated production functions

\begin{tabular}{lccccccccc}
\hline & Half-Normal & \multicolumn{2}{c}{ Truncated Normal } & Exponential & \multicolumn{2}{c}{ Gamma } \\
& CRS & VRS & CRS & VRS & CRS & VRS & CRS & VRS \\
\hline Variable & Coef. & Coef. & Coef. & Coef. & Coef. & Coef. & Coef. & Coef. \\
\hline Constant & $3.23^{*}$ & $3.23^{*}$ & $3.16^{*}$ & $3.15^{*}$ & $3.13^{*}$ & $3.13^{*}$ & $3.23^{*}$ & $3.06^{*}$ \\
Ln (Land) & 0.05 & 0.03 & 0.05 & 0.03 & 0.05 & 0.03 & 0.06 & 0.02 \\
Ln (Labor) & -0.007 & 0.004 & -0.002 & 0.007 & 0.0001 & 0.01 & -0.003 & 0.01 \\
Ln (Machinery) & $0.17^{*}$ & $0.18^{*}$ & $0.18^{*}$ & $0.17^{*}$ & $0.17^{*}$ & $0.17^{*}$ & $0.17^{*}$ & $0.17^{*}$ \\
Ln (Fertilizer) & $0.76^{*}$ & $0.76^{*}$ & $0.77^{*}$ & $0.76^{*}$ & $0.77^{*}$ & $0.76^{*}$ & $0.76^{*}$ & $0.76^{*}$ \\
Ln (Pesticide) & 0.02 & 0.02 & 0.01 & 0.01 & 0.01 & 0.01 & 0.01 & 0.02 \\
RTS ( $\left.\sum \beta_{i}\right)$ & 1 & 0.99 & 1 & 0.98 & 1 & 0.98 & 1 & 0.98 \\
LLHF & -10.81 & -10.18 & -10.81 & -10.18 & -10.81 & -10.18 & -10.81 & -10.18 \\
\hline LLHF-OLS & -7.59 & -7.53 & -7.01 & -6.96 & -7.11 & -7.05 & -6.58 & -6.28 \\
\hline
\end{tabular}

*Significant at 0.05 significance level

The soils in the region are generally poor compared to the middle and forest belts of the country. The most important soil nutrients, nitrogen and phosphorous are low compared to other regions (FAO, 2005). This could explain the relatively higher coefficient since they 
form the basic components of compound fertilizers used in the region. Machinery use is the input with the second highest output elasticity. Agricultural mechanization in the region is low, because many of the farm activities are labor intensive. Apart from ploughing and sometimes transportation of harvest, farmers hardly use machines for sowing, weeding, fertilizer application and harvesting. The abundance of family labor which is assumed to be free may be responsible for the reluctance to use machines. It could also be a problem of access, especially tractors (Amankwah et al., 2012). Farmers often lack access to the use of tractors at the start of the farming season. Land and pesticide use were third and fourth depending on the distribution and the RTS assumption.

Labor, which is the input of interest, has consistently been the least in terms of output elasticity across all the assumptions. It is the only input with a negative coefficient under the CRS assumption for all the distributions except for exponential. Even the positive value under the exponential distribution is very negligible; close to zero. Under the CRS assumption which has been affirmed to be the appropriate RTS assumption for this study, any addition of labor will lead to a reduction in output. This indicates over use of labor input in agricultural production in the region. Labor is found to be the worse marginal contributor to output. The family labor to total labor ratio is 0.956 , indicating more than $95 \%$ of the agricultural labor are family labor. With this information, it is expected that the amount of agricultural labor is highly correlated with fertility rate in the region. The region has consistently topped all regions in terms of fertility rate since 1988. The Northern region's fertility rate is 6.8 children compared with the Greater Accra region (the biggest destination of Kayayee) of 2.5 children (Agyei-Mensah and Owoo, 2015). This clearly indicates that the region is producing more agricultural labor than what agricultural production needs. This has manifested in the low and negative output elasticity for labor under all possible assumptions.

\subsection{Input Allocation}

The estimation of the RAC is to demonstrate which inputs should be increased, unchanged or decreased in order to achieve maximum profit or income. From the table, the RAC of land size for both CRS and VRS under all the distributional assumption are less than one. This indicates that under all assumptions land is excessively used, hence it would require a reduction. From a combined database of MoFA and the FAOSTAT, Abukari et al. (2015) revealed that most of the agricultural outputs in the Northern region are below $50 \%$ of their potential per land size. They further added that, productivity, which is measured per land size for most of the important food crops are declining over the years. While the national productivity of cassava, yam, maize, rice and soybean improved from 2010 to 2013, the Northern region saw a decline with the exception of tubers. It is therefore not surprising that the RAC for land size is consistently less than one, even though it consistently recorded positive output elasticity.

Machinery and fertilizer use have consistently recorded a positive RAC across all the assumptions. This indicates that, they are underutilized. Per the coefficient, more machines and fertilizers should be used in the production, which probably reflect an IRS in the use of these inputs. The use of machines would be in direct conflict with the use of labor, which is 
supposedly free. Fertilizer application is greatly underutilized considering the larger RAC. It is known that fertilizer usage in Sub Sahara Africa (SSA) is very low, and in the specific case of the Northern region, the work of Chapoto et al. (2015) proves this point. The government claimed to increase the supply of fertilizers at subsidized prices every year. If that is the case, it means that the farmers might be buying much, but misusing it in application. Gerken et al. (2001) has confirmed the misapplication of chemicals in the agricultural sector. This study cannot investigate this claim because the fertilizer quantities were not collected per crop.

Table 4. Resource allocation coefficients for all distributions

\begin{tabular}{|c|c|c|c|c|c|c|c|c|c|}
\hline & \multicolumn{2}{|c|}{ Half-Normal } & \multicolumn{2}{|c|}{ Truncated Normal } & \multicolumn{2}{|c|}{ Exponential } & \multicolumn{2}{|c|}{ Gamma } & \multirow{2}{*}{$\begin{array}{l}\text { Geometric Means } \\
\overline{\bar{Y}}=6706.68\end{array}$} \\
\hline Variable & CRS & VRS & CRS & VRS & CRS & VRS & CRS & VRS & \\
\hline Land size & 0.256 & 0.126 & 0.242 & 0.145 & 0.242 & 0.145 & 0.290 & 0.097 & 13.88 \\
\hline Labor & -0.007 & 0.004 & -0.002 & 0.007 & 0.0001 & 0.010 & -0.003 & 0.010 & 2401.24 \\
\hline Machinery & 1.899 & 1.932 & 1.987 & 1.877 & 1.877 & 1.877 & 1.877 & 1.877 & 42.48 \\
\hline Fertilizer & 3.679 & 3.655 & 3.708 & 3.660 & 3.708 & 3.660 & 3.660 & 3.660 & 732.98 \\
\hline Pesticide & - & - & - & - & - & - & - & - & 118.52 \\
\hline
\end{tabular}

Labor's coefficient is lowest in terms of the RAC. It is not only less than one, but negatives under the CRS assumption. This indicates a much significant overuse of this input. This suggests a significant reduction in the quantity used. Farmers would suffer a heavy loss if they increase the use of labor; that is, the income that would be earned from the unit increase of labor would be far lower than the unit price of labor. In summary, it means more fertilizers and machinery should be substituted for labor and land size in agricultural production in the region.

\subsection{Slack Analysis}

The non-stochastic slack analysis is represented in Table 5. It shows both RTS assumptions. The mean input slacks for all the inputs under CRS and VRS are represented in Table 5, but they do not tell the story. Its percentage of the total input used is the point of discussion. That is, what percentage of each input employed is wasted, making production inefficient. It has been demonstrated that under the stochastic techniques there is inefficiency in agricultural production. It can be observed from the table that about $25 \%$ of the labor employed are slacks, making it the most wasted input. This confirms the results in the RAC that, labor is 
over utilized relative to the other inputs. That means additional labor employment has contributed more to production inefficiency. Closely following it is pesticide use, land size, machinery and fertilizer in that order.

Table 5. Input slacks

\begin{tabular}{ccccccccccc}
\hline & $\begin{array}{l}\text { Land } \\
\text { Size(Acre) }\end{array}$ & \multicolumn{2}{l}{ Labor Hours } & \multicolumn{2}{l}{$\begin{array}{l}\text { Machinery } \\
\text { Hours }\end{array}$} & Fertilizer (Kg) & $\begin{array}{l}\text { Pesticide } \\
\text { (GHC) }\end{array}$ & Use \\
& CRS & VRS & CRS & VRS & CRS & VRS & CRS & VRS & CRS & VRS \\
\hline $\begin{array}{l}\text { Mean } \\
\text { Inputs }\end{array}$ & 16.9 & 16.9 & 3627.4 & 3627.4 & 55.7 & 55.7 & 931.7 & 931.7 & 164.5 & 164.5 \\
$\begin{array}{l}\text { Mean } \\
\text { Slacks }\end{array}$ & 0.9 & 1.3 & 927.6 & 948.8 & 2.3 & 3.5 & 5.9 & 77.1 & 25.7 & 33.0 \\
$\begin{array}{l}\text { \% as } \\
\text { Slacks }\end{array}$ & 5.6 & 7.7 & 25.6 & 26.2 & 4.1 & 6.3 & 0.6 & 8.3 & 15.6 & 20.1 \\
\hline
\end{tabular}

\section{Conclusions and Recommendations}

Even though the reviews of the implemented policies are not in-depth, it has been shown that the combined effect of these policies is not felt on the reduction of Kayayee migrants, as witnessed in the continuous increasing numbers. It could be due to the fact that, none of the policies had it as their main objective in the first place. However, what is more obvious is the fact that most of them suffered funding and implementation challenges. The short lived success of the OFY implies that, a massive revolution in agriculture will not only reverse the migration trend, but will bridge the poverty gap between the north and the south.

All the various analyses that seek to unearth the relationship between labor and agricultural employment have arrived at a similar conclusion. Like the industrial and services sectors in the region, agricultural production is equally rejecting these labor, albeit in a different way. While the former places education and skills barriers to their entry, agriculture rejects them by exhibiting lower labor productivity (output elasticities), lower profit/income (RAC) and higher production inefficiency (input slacks) relative to other factors of production. These results have all demonstrated that a reduction in the quantity of labor input would be better for agricultural production. That is, the agricultural structure of the region cannot support the labor. The case of labor is unique in the sense that it is difficult to adjust since almost all the labors are family labor. For instance, like labor, the RAC also recommended a reduction in land size. However, the implementation of this conclusion in terms of land size is easy while the reduction of labor in some cases is almost impossible. The situation would have been different if labor were hired. Labor addition has reflected in lower productivity and lower profit/income which is reflected in the lack of jobs and incomes which they alternatively try 
seeking from the kayaye business.

In the light of our findings, we recommend that there should be a policy purposely targeting the reduction and subsequent elimination of this business, considering its health, social and psychological effects on the development of the female child especially. There is no known government policy to curb this business. It is only fair and logical that a deliberate policy in the colonial era that triggered this phenomenon should be countered with a deliberate policy to reverse it. This policy should be deeply grounded in the push factors than the pull factors. In the continuous rejection of labor in the agricultural production in the region, no amount of solutions in the host cities will solve the entire problem. It should target the expansion of agriculture to make use of the labor more efficiently. The policy should include the development of the tree crops in the region, as they are found to employ a lot of people in the dry season. Lastly, in line with government educational policies, females who make up the chunk in this business should be given priority.

Since it has been found that agriculture does not need most of the labor, the following recommendations suggest ways this surplus labor can be engaged. Irrigation facilities should be expanded to enable all year round farming, especially for those that are completely unemployed in the dry seasons. Returnee migrants should be tracked and supported since they have a higher chance of returning. Those of them who intend using their money to start a business or continue their education should be the focus of this support to achieve their objective. The ultimate solution from our point of view is to reduce the number of children per household. The high fertility and birth rates which result in the increase of these labors should be reduced. This recommendation unlike the others is a long term one. Family planning education has to be intensified in the region so as to achieve this.

\section{References}

Abukari, A. T., Öztornaci, B., \& Budak, D. B. (2015). Prioritizing needs assessment techniques for agricultural programs implementation: The case of Northern Region, Ghana. Journal of Agricultural Extension and Rural Development, 7(12), 330-340.

http://dx.doi.org/10.5897/JAERD2015.0620

Adaawen, S. A., \& Owusu, B. (2013). North-South migration and remittances in Ghana. African Review of Economics and Finance, 5(1), 29-45.

Adepoju, A. (1986). An overview of rural migration and agricultural labour force structure in Africa. Population Studies, 1, 5-25.

Agyei, Y. A., Kumi, E., \& Yeboah, T. (2016). Is better to be a kayayei than to be unemployed: reflecting on the role of head portering in Ghana's informal economy. GeoJournal, 81(293). http://dx.doi.org/10.1007/s10708-015-9620-z

Agyei-Mensah, S. \& Owoo, N. S. (2015). Explaining Regional Fertility Variations in Ghana. J Pop Research, 32, 157. http://dx.doi.org/10.1007/s12546-015-9147-7

Al-hassan, S. (2012). Market Access Capacity of Women Shea Processors in Ghana. European Journal of Business and Management, 4(6). ISSN 2222-1905 (Paper) ISSN 
2222-2839 (Online)

Al-hassan, S. (2016). Ghana's Shea Industry: knowing the fundamentals. Institute for Continuing Education and Interdisciplinary Research (ICEIR)

Amankwah, K., Klerkx, L., ..., \& Millar, D. (2012). Diagnosing constraints to market participation of small ruminant producers in northern Ghana: an innovation systems analysis. J. Life Sci., 60-63, pp. 37-47. http://dx.doi.org/10.1016/j.njas.2012.06.002

Anarfi, J., K., \& Kwankye, S. (2005). The costs and benefits of children's independent migration from northern to southern Ghana. Paper presented at the International Conference on Childhoods: Children and Youth in Emerging and Transforming Societies. Oslo, Norway.

Asante, E. A. (2012). The case of Ghana's president's special initiative on oil palm (PSI-oil palm). DIIS Working Paper 2012:11.

Asare, P. (2012). Labour Migration in Ghana. Friedrich-Ebert-Stiftung, Ghana.

Awumbila, M. (2007). Internal Migration, Vulnerability and Female Porters in Accra, Ghana. http://paa2007.princeton.edu/papers/70865 (Access Date: July 2016).

Awumbila, M., Manuh, T., ..., \& Antwi Bosiakoh, T. (2008). Migration country paper (Ghana). Accra, Ghana: Center for Migration Studies, University of Ghana.

https://www.imi.ox.ac.uk/news/programme-papers-published/ghana-country-paper-2008.pdf (Access Date: December 2015)

Chapoto, A, Sabasi, D., \& Asante-Addo, C. (2015). Fertilizer Intensification and Soil Fertility Impact on Maize Yield Response in Northern Ghana. Selected Paper prepared for presentation at the Agricultural \& Applied Economics Association's 2015 AAEA Annual Meeting, San Francisco, California, CA, July 26-28, 2015

Choudhary, V., Christienson, G., Josserand, H., \& D'alessandro, S. (2015). Ghana: Agricultural Sector Risk Assessment-Risk Prioritization. Agriculture Global Practice Technical Assistance Paper. World Bank Group Report Number 94228-Gh

Coelli, T. J., Prasada, R. D. S., O Donnell, C.J., \& Battese, G. E. (2005). An Introduction to Efficiency and Productivity Analysis, 2nd Edition, Springer, New York, $366 \mathrm{P}$

Cooper, W. W., Seiford, L. M., \& Tone, A. (2007). Data Envelopment Analysis: A Comprehensive Text with Models, Applications, References and DEA-Solver Software. Second Edition. New York: Springer.

Dilmen, B. (1976). Gaziantep Merkez Yöresinde Antep Fıstığı Üretiminin Ekonomik Analizi, Atatürk Ünv. Yayınları No: 447, Atatürk Üniversitesi Matbaası, 49 S. Erzurum, Turkey

Egyir, I. S. (2013). Making Youth Engagement in Agriculture a Reality. The Economy of Ghana Network (EGN). Institute of Statistical Social and Economic Research (ISSER). Policy Brief: No. 07.

FAO (Food and Agriculture Organization) (2005). Fertilizer Use by Crop in Ghana. 
International Fertilizer Industry Association (IFA). Land and Plant Nutrition Management Service; Land and Water Development Division of Fao. Fao, Rome, 2005 Ftp://Ftp.Fao.Org/Docrep/Fao/008/A0013e/A0013e00.Pdf (Access Date: December 2015)

Gerken, A. Suglo, J. \& Braun, M. (2001). Pesticides Use and Policies in Ghana. An Economic and Institutional Analysis of Current Practice and Factors Influencing Pesticide Use. 2001, Hanover: A Publication of the Pesticide Policy Project. Publication Series, Hanover University

Girdner, J., Olorunsola, V., Froning, M. \& Hansen, E. (1980). Ghana's agricultural food policy - Operation Feed Yourself. Food Policy 5 (1), 14-25.

http://dx.doi.org/10.1016/0306-9192(80)90021-4

Grazhdaninova, M., \& Lerman, Z. (2005). Allocative and Technical Efficiency of Corporate Farms in Russia. Comp. Econ. Stud. 47, 200-213.

GSS (Ghana Statistical Service) (2012). 2010 Population and Housing Census. Summary Report of Final Results.

http://www.statsghana.gov.gh/docfiles/2010phc/Census2010_Summary_report_of_final_resul ts.pdf (Access Date: December 2016)

GSS (Ghana Statistical Service) (2013). 2010 Population and Housing Census Report; Men and Women in Ghna. UNFPA.

http://www.statsghana.gov.gh/docfiles/publications/2010phc_monograph_women_\&_men_in _Gh.pdf (Access Date: December 2015)

GSS (Ghana Statistical Service) (2014). Ghana Living Standards Survey (GLSS6); Main Report. http://www.statsghana.gov.gh/docfiles/glss6/GLSS6_Main\%20Report.pdf (Access Date: December 2015)

Jawula, M. N. D. (2010). Kayaye in Ghana - A Case of Policy Failure. Feature Article of Wednesday, 1 September 2010. Ghanaweb.com

Kainth, G. S. (2010). Push and Pull Factors of Migration: A Case Study of Brick Kiln Migrant Workers in Punjab. Guru Arjan Dev Institute of Development Studies, Amritsar. Munich Personal RePEc Archive (MPRA) Paper No. 30036.

Kearney, H. (2013). Ghana's female porters get family planning advice. The International Development Journalism finalists 2013. The Guardian.

https://www.theguardian.com/global-development-professionals-etwork/2013/nov/22/ghanasfemale-porters-get-family-planning-advice (Access Date: July 2016)

King, R. (2012). Theories and Typologies of Migration: An Overview and a Primer. Willy Brandt Series of Working Papers in International Migration and Ethnic Relations 3/12. Malmö Institute for Studies of Migration, Diversity and Welfare (MIM). ISSN 1650-5743 / Online publication

Kumbhakar, S. C. \& Lovell K., C.A. (2000). Stochastic Frontier Analysis. Cambridge University Press, Cambridge. 


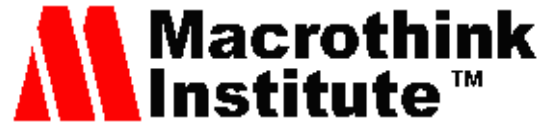

Journal of Agricultural Studies

ISSN 2166-0379

2017, Vol. 5, No. 2

Kwankye, S. O., Anarfi, J. K., Tagoe, C. A., \& Castaldo, A. (2007). Coping strategies of independent child migrants from northern Ghana to southern cities. Migration DRC Working Paper T-23. University of Sussex, Brighton: Development Research Centre on Migration, Globalisation and Poverty.

Lucas, R. (1997). Internal migration in developing countries. In 'The Handbook of Population and Family Economics'. M. Rozenweig and O. Stark (Eds.). Amsterdam: Elsevier, chapter 13, 721-798.

Lucas, R. (2015). Internal migration in developing economies: An overview. Working Paper No. 6. Washington, DC: Global Knowledge Partnership on Migration and Development (KNOMAD).

Mahama, E.S.K. (2015). Kayayo menace in the Context of Wa East District in Ghana. Public Policy and Administration Research, 5(5). ISSN 2225-0972(Online)

MoFA (Ministry of Food of Agriculture). (2004). Policy document: Livestock Development Policies and Strategies (2004-2015). http://faolex.fao.org/docs/pdf/gha148233.pdf (Access Date: December 2016)

MoFA (Ministry of Food of Agriculture). (2012). Policy document: Tree Crops Policy. Agence Française de Développement (French Cooperation Agency).

https://drive.google.com/file/d/0B4fn1Fz6J8K9OVBQQTY0UWVYdXM/view (Access Date: September 2016)

MoFA (Ministry of Food of Agriculture) (2013). 2013 Agricultural Sector Annual Progress Report. Monitoring and Evaluation Directorate.

http://mofa.gov.gh/site/wp-content/uploads/2014/06/2013-Agric-Sector-Annual-Progress-Rep ort.pdf (Access Date: December 2015)

MoFA (Ministry of Food of Agriculture) (2014). 2014 Agricultural Sector Annual Progress Report. Monitoring and Evaluation Directorate.

http://mofa.gov.gh/site/wp-content/uploads/2015/07/Agric\%20Report\%202014.pdf (Access Date: October 2015)

MoFA (Ministry of Food of Agriculture) (2016). Policy document: Livestock Development Policies and Strategies (2016-2025).

http://mofa.gov.gh/site/wp-content/uploads/2016/11/GHANA-LIVESTOCK-DEVELOPMEN T-POLICY-AND-STRATEGY-final.pdf (Access Date: December 2016)

Opare, J. A. (2003). Kayayei: The Women Head Porters of Southern Ghana'. Journal of Social Development in Africa, 18(2):33-48. http://dx.doi.org/10.4314/jsda.v18i2.23825

Ramanathan, R. (2003). An Introduction to Data Envelopment Analysis: A Tool for Performance Measurement. Sage Publications, New Delhi.

Rasmussen, S. (2011). Production Economics: The Basic Theory of Production Optimisation. e-ISBN 978-3-642-14610-7. Springer Heidelberg Dordrecht London New York 


\section{Macrothink}

Journal of Agricultural Studies

ISSN 2166-0379

2017, Vol. 5, No. 2

Silva, E., Mendes, A. B., \& Santos, J. (2013). Efficiency Measures in the Agricultural Sector: The Beginning. In "Efficiency Measures in the Agricultural Sector: With Applications". Mendes, A.B., Soares da Silva, E.L.D.G., and Santos J.M.A. (Eds.), ISBN 978-94-007-5738-7, Springer Science+Business Media Dordrecht 2013, pp.3-12.

Tanle, A. (2014). Assessing livelihood status of migrants from northern Ghana resident in the Obuasi Municipality. GeoJournal, 79(5), 577-590.

http://dx.doi.org/10.1007/s10708-013-9514-x

Thet, K. K. (2014). Pull and Push Factors of Migration: A Case Study in the Urban Area of Monywa Township, Myanmar. Research Report. The World of Statistics. March 24, 2014 Volume 1, Issue 4

UNFPA (United Nations Population Fund) (2013). Kayayee/Female Porters: Improving Sexual and Reproductive Health (SRH) Knowledge and Legal Literacy. Good Practices for the 5th Country Program (CP5). Brochure. Evidence and Action. Special Issue http://unfpaghana.org/assets/user/file/KAYAYEE.pdf (Access Date: November 2016)

Van den Berg, C. (2007). The Kayayei Survival in the City of Accra. Social Capital and Vulnerability in the Lives of Female Head Porters in Accra, Ghana. Unpublished MSc. Thesis presented to the International School for Humanities and Social Sciences, University of Amsterdam. http://dare.uva.nl/cgi/arno/show.cgi?fid=99131 (Access Date: October 2016)

Wolken, L. (1970). Output Elasticity and the Product Curves. The American Economist, 14(2), 59-61. Sage Publications, Inc.

Woode, R. (2012). Third World to First World - By One Touch: Economic Repercussions of the Overthrow of Dr. Kwame Nkrumah. ISBN: 9988165196,9789988165192

Wrigley-Asante, C. (2013). Survival or escaping poverty: The perspectives of poverty and well-being among Ghanaian women in cross-border trading. Journal of Gender Studies, 22(3), 320-334. http://dx.doi.org/10.1080/09589236.2012.703519

\section{Copyright Disclaimer}

Copyright for this article is retained by the author(s), with first publication rights granted to the journal.

This is an open-access article distributed under the terms and conditions of the Creative Commons Attribution license (http://creativecommons.org/licenses/by/4.0/). 